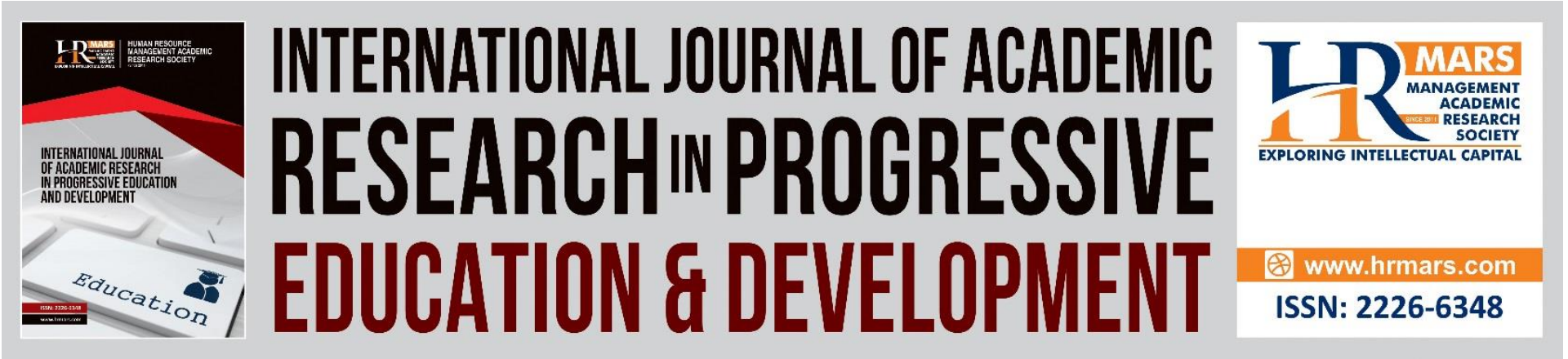

\title{
Lecturers' Perceptions towards Students' English Language Proficiency: A Preliminary Study
}

Janaki Manokaran, Soh, Or-Kan, Hazita Azman

To Link this Article: http://dx.doi.org/10.6007/IJARPED/v10-i2/10461

DOI:10.6007/IJARPED/v10-i2/10461

Received: 07 April 2021, Revised: 12 May 2021, Accepted: 27 May 2021

Published Online: 21 June 2021

In-Text Citation: (Manokaran et al., 2021)

To Cite this Article: Manokaran, J., Soh, O.-K., \& Azman, H. (2021). Lecturers' Perceptions towards Students' English Language Proficiency: A Preliminary Study. International Journal of Academic Research in Progressive Education and Development, 10(2), 957-963.

Copyright: (C) 2021 The Author(s)

Published by Human Resource Management Academic Research Society (www.hrmars.com)

This article is published under the Creative Commons Attribution (CC BY 4.0) license. Anyone may reproduce, distribute, translate and create derivative works of this article (for both commercial and non-commercial purposes), subject to full attribution to the original publication and authors. The full terms of this license may be seen

at: http://creativecommons.org/licences/by/4.0/legalcode

Vol. 10(2) 2021, Pg. 957 - 963

http://hrmars.com/index.php/pages/detail/IJARPED

JOURNAL HOMEPAGE

Full Terms \& Conditions of access and use can be found at http://hrmars.com/index.php/pages/detail/publication-ethics 


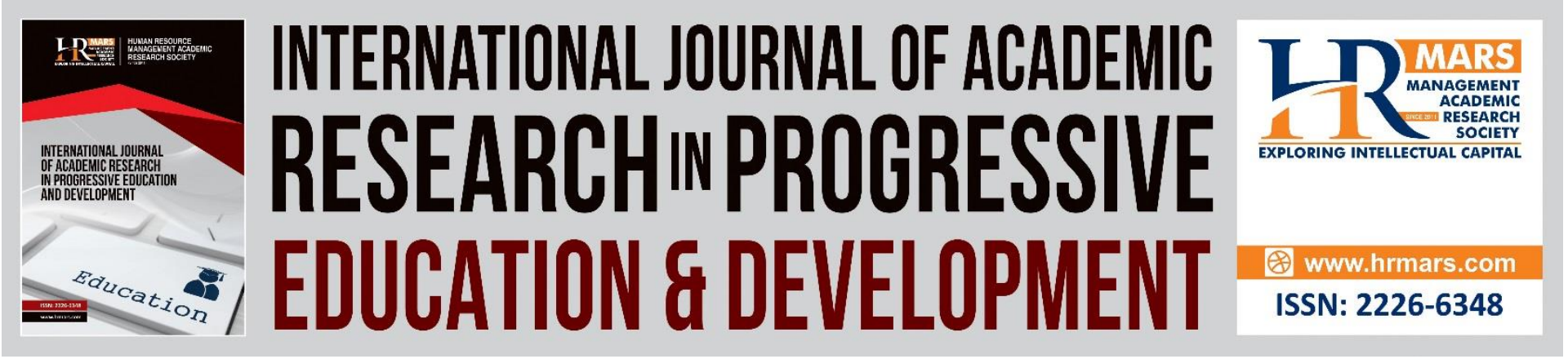

\title{
Lecturers' Perceptions towards Students' English Language Proficiency: A Preliminary Study
}

\author{
1 Janaki Manokaran, ${ }^{2}$ Soh, Or-Kan, ${ }^{3}$ Hazita Azman \\ Centre for Research in Language \& Linguistics, Faculty of ocial Sciences \& Humanities, \\ Universiti Kebangsaan Malaysia (UKM) \\ 2Email: sok@ukm.edu.my
}

\begin{abstract}
Realizing the fact that English is the second most important language in Malaysia, the education system emphasises the importance of language among students in schools and higher learning institutions. Students' Language proficiency is vital to excel in their studies and directly influencing better job opportunities upon graduation as employers prioritise in hiring candidates who are competent in English. Unfortunately, many employers in Malaysia reluctant to hire graduates due to their lack of proficiency in English. English language learning has always been a challenge to majority Malaysian students despite undergo 11 years of formal education. Thus, this study aims at exploring lecturers' perception towards students' English language proficiency. Survey was used to collect data from 50 English lecturers. The findings shed lights on several important sections - Teaching Environment, Language Skills Areas and Teaching Approaches. It is an undeniable fact that in the process of teaching and learning, learners have different abilities in acquiring and mastering a language. Lecturers' perception towards students' English language proficiency is vital in second language research literature. This provides a rich information on learners' abilities and inabilities on learning the target language and very useful for the lecturers to plan their lessons according to the learners' needs.
\end{abstract}

Keywords: Lecturers' perception, English Language Proficiency

\section{Introduction}

After independence, Malay language was proclaimed as the National Language. However, English Language has a vital role to play. English Language was declared as a second language in Malaysia and is taught as a compulsory subject from Standard One to Form Five. English is also widely used by many as the medium of communication in Malaysia.

Realizing the fact that English is the second most important language in Malaysia, the education system is emphasising the importance of language among students in schools and higher learning institutions. Malaysian education system focuses on the importance of English Language teaching to empower students from schools and higher learning institutions to be able to use the language in everyday situations, knowledge acquisition and future needs in career. 
With the country's vision to be a developed nation, the Malaysia Higher Education Blueprint (2015 - 2025) aspires at creating a higher education system that trains people necessary for academic and manpower needs for the nation. A good command proficiency of English is important for all kinds of professional and personal goals (Nishanti,2018)

Students English Language proficiency is vital for them to excel in their studies and directly influencing better job opportunities upon graduation as employers prioritise in hiring candidates who are competent in English. According to Academic Achievements and Employability of Graduates in institutions of Higher Learning (Morshidi et al., 2004), various English Language proficiency have significant effects towards employability (Atek et al., 2012).

Yahaya et al (2011) stated that many employers in Malaysia reluctant to hire graduates due to their lack of proficiency in English. English language learning has always been a challenge to majority Malaysian students despite undergo 11 years of formal education in school. Thus, this study aims at exploring lecturers' perception towards students' English language proficiency. Hence, this study will accomplish the following objective:

\section{To Explore Lecturers' Perceptions towards Tertiary Students' English Language Proficiency}

English language lecturers' perceptions towards students' English language proficiency, their strength and weakness are vital as it could serve as a base for further research and investigation.

The focus on the English lecturers' perception on students' language proficiency may influence how well their students perform toward the subject. (Susanto, Salleh and Fazlinda., 2008). The lecturers' perceptions towards their students' language proficiency is the primary information in describing the real phenomenon of English learning among the tertiary students before further investigation to be done.

According to $\mathrm{MOE}$, higher/ tertiary education plays the utmost important role in developing skilled and knowledgeable human capital. Its vision is to make Malaysia a center of education excellence as upon completion of the higher/tertiary education, the graduates are open to economic and career opportunities of their own choice. Similarly, Zain, Aspah, Mohmud, Abdullah and Ebrahims, 2017, claim that higher/tertiary education produces citizens who are educable for life and responsible to contribute to social harmony and improved living standards. So, considerable amount of attention is needed to ensure effective teaching and learning of the language that enable students to have a full command over it.

\section{Research Method}

\section{Participants}

All the lecturers from the Academy of Language Studies, Centre of Foundation Studies Department, UiTM Cawangan Selangor, Kampus Dengkil participated in this research. The total number of these lecturers was 50 .

\section{Research Design}

The research design that is applied in this study is a non-experimental survey design. Nonexperimental survey design is a suitable method to use in finding out the thoughts and views of a large number of people (Chan, 2020). 
DEVELOPMENT

Vol. 10, No. 2, 2021, E-ISSN: 2226-6348 @ 2021 HRMARS

\section{Research Instrument}

The main instrument designed for the study is a self-designed questionnaire on lecturers' perceptions towards students' English proficiency. The questionnaire contained two (2) sections. Section 1 on respondents' background information and section 2 required responses of alternative option, from the respondents on their perceptions.

\section{Procedure}

This research was conducted at the Center of Foundation Studies, Universiti Teknologi MARA, Cawangan Selangor, Kampus Dengkil and focused on English lecturers from the Department of Academy of Language Studies. The data were collected using Google Form. The link was shared with the English lecturers who responded to and submitted the responses online. The data were analysed using descriptive statistical methods and SPSS (Version 25).

\section{Result and Discussion}

\section{a) Teaching Environment}

Table 1: Number of teaching experience

\begin{tabular}{|l|l|}
\hline Number of years & Percentage \\
\hline Less than a year & $8 \%$ \\
\hline $1-5$ years & $60 \%$ \\
\hline $6-10$ years & $20 \%$ \\
\hline $11-15$ years & $4 \%$ \\
\hline $16-20$ years & $2 \%$ \\
\hline More than 20 years & $6 \%$ \\
\hline
\end{tabular}

Table 1 illustrated the years of teaching experience of the respondents in this study. 60 percent of the lecturers are having $1-5$ years teaching experience. 20 percent for $6-10$ years, 8 percent (less than a year). Meanwhile 4 percent for $11-15$ years, $16-20$ years ( 2 percent) and more than 20 years of teaching experience ( 6 percent). These various teaching experiences is an apt indicator of lecturers' perceptions towards students' English Language Proficiency as different lecturers will have various opinions and perceptions in this study. This collaboration of experienced and novice lecturers is vital as it is being helpful not only in the productivity of experienced lecturers but also that of other novice lecturers who can learn from them (Podolsky, Kini \& Darling-Hammond, 2019).

\section{b) Language Skill Areas}

Table 2: Teaching Skills Areas

\begin{tabular}{|l|l|l|l|}
\hline $\begin{array}{l}\text { Teaching Skill } \\
\text { Areas }\end{array}$ & Percentage & Mean & SD \\
\hline Writing Skill & $48 \%$ & 0.48 & 0.505 \\
\hline Speaking Skill & $30 \%$ & 0.30 & 0.463 \\
\hline Listening Skill & $6 \%$ & 0.06 & 0.246 \\
\hline Reading Skill & $16 \%$ & 0.16 & 0.370 \\
\hline
\end{tabular}

More than few decades, the research on teaching and learning of English language has identified the four skills, writing, speaking, listening and reading as of foremost importance. 
Therefore, a great amount of focus is put on the teaching and learning of these four skills of English. The current study indicated the concerns of students' state of proficiency regarding the language skills.

Out of all the language skills, writing is found the most difficult skill to acquire by the students with the highest mean score of $M=0.48$ as indicated in Table 2, 48 percent lecturers showed strong agreement with this statement. The lecturers agreed that their students are poor in Writing Skills. This is supported by Fareed, Ashraf and Bilal (2016), who opine that writing skill is considered a difficult skill, particularly in ESL context where students face many challenges acquiring the skill. Writing can be a devastating process to the students because it does not only about generate and organizing ideas from our minds but also put forward these ideas into readable texts.

In contrast to this skill, around $3(\mathrm{M}=0.06)$ respondents of this study mentioned that listening skill is the least problematic skill to acquire among their students. This phenomenon is closely related to the findings reported by Ulum(2015) which states that listening skill as the ignored language skill and being underestimated in research literature compared to the other three skills of English. Reading skill indicated a mean score of $M=0.16$ meanwhile speaking skill, $\mathrm{M}=0.30$.

Table 3: Specific Skill

\begin{tabular}{|l|l|l|l|}
\hline Specific Skills & Percentage & Mean & SD \\
\hline Content & $12 \%$ & 0.12 & 0.328 \\
\hline Grammar & $84 \%$ & 0.84 & 0.370 \\
\hline Organisation & $4 \%$ & 0.04 & 0.198 \\
\hline
\end{tabular}

Regardless of the four language skills of English, the respondents showed strong agreement in the area that grammar is the most difficult skill to acquire by their students. This is indicated by the highest mean score if $M=0.84$ as shown in Table 3 . This result is further supported by similar findings by Han and Kim (2017), claimed that learners have low proficiency level in grammar. Furthermore, some students did not know the correct grammatical features and this is due to their lack of knowledge and grammatical competency (Refnita,2014).

In addition, the respondents agreed that the students' least problematic area is organization with the lowest mean score, $M=0.04$. Lecturers also indicated that students have problem in developing content $(\mathrm{M}=0.12)$ especially in writing and speaking.

\section{c) Teaching Approaches}

Teaching grammar and coming up with grammar lessons might be more difficult that what people thought. According to Azar (2007), the grammar lessons have to balance in fulfilling the students' needs and achieving the devastating process for the students. The students perceive it as the boring skill as they do not find the grammar lessons effective and interesting (Nguyen,2010).

Therefore, there is a need for lecturers to find interesting and effective ways to teach grammar so that not only students can be motivated but also students can place their full energy to language learning. This notion is well supported by the respondents where $60 \%$ of them agreed that Game-Based grammar lesson is an effective tool and teaching approach in English language teaching and learning. Previous studies have shown the effectiveness in using games to teach grammar (Hashim et al, 2019; Yolageldili and Arikam, 2011; Baharudin and Yunus, 2018). These findings have proven that using game-based grammar approach in teaching has 
a very positive effect on students' acquisition of grammar. Game-based grammar learning also provided the opportunity for the students to learn and practice in an authentic environment. This is viewed as paramount important as the usage and practice of language in an authentic environment provide an effective reinforcement in the learning process (Hamzah and Dourado, 2010)

\section{Conclusion}

This study aims at exploring lecturers' perception towards students' English language proficiency. It is an undeniable fact that in the process of teaching and learning, learners have different abilities in acquiring and mastering a language. Regardless of the four skills of English, different learners have different capabilities and incapabilities in learning the language. Despite going through 11 years of learning English, many students are still unable to attain reasonable English literacy (Naginder, 2006; Jalaludin, Awal and Abu Bakar,2008). Lectures' commitment to address this problem is utmost important.

Lecturers' perception towards students' English language proficiency is vital in second language research literature. This provides a rich information on learners' abilities and inabilities on learning the target language. This is very useful for the lecturers to plan their lessons according to the learners' needs as the lecturers can emphasis on the poor language skills of English from the findings of the lecturers' perceptions. 


\section{References}

Atek, E. S. E., Josoh, J., Alias, A. N., Wahid, A. W., \& Tahir, I. M. (2012). Students' attitudes towards the English proficiency enhancement program. International Journal of Education, 4(3), 1-11. https://doi.org/10.5296/ije.v4i3.1475

Azar, B. (2007). Grammar-based teaching: A practitioner's perspective. Teaching English as a Second or Foreign Language E-Journal, 11(2), 1-12.

Baharudin, N. A. A. \& Yunus, M. M. (2018). GRAMMODO: a platform in learning grammar among ESL learners in Malaysia. Innovation for Sustainable Growth, 106-108. Langkawi: International Invention and Innovative Competition (InIIC).

Fareed, M., Ashraf, A., \& Bilal, M. (2016). ESL Learners' Writing Skills: Problems, Factors and Suggestions. Journal of Education \& Social Sciences, 492, 81-92.

Hamzah, M. H., \& Dourado, J. E. (2010). Using grammar games in teaching grammar: A case study inSMK Damai Jaya. Retrieved from http://eprints.utm.my/10214/2/ Juliana_Emilia_Dourado.pdf

Han, K., \& Kim, H. (2017). An investigation into the gap between Korean university students' grammatical awareness and perception. Indonesian Journal of Applied Linguistics, 7(1), 117-126. Retrieved fromhttp://ejournal.upi.edu/index.php/IJAL/article/view/6864

Hashim, H., M. Rafiq, K. R., \& Yunus, M. M. (2019). Improving ESL Learners' Grammar with Gamified-Learning. Arab World English Journal, (5), 41-50. https://doi.org/10.24093/awej/call5.4

Minh, N. T., \& Tuan, L. T. (2010). Teaching English Grammar Through Games. Studies in Literature and Language, 1(7), 61-75.

Nishanthi, R. (2018). The Importance of Learning English in Today World. International Journal of Trend in Scientific Research and Development, Volume-3(Issue-1), 871-874. https://doi.org/10.31142/ijtsrd19061

Podolsky, A., Kini, T., \& Darling-Hammond, L. (2019). Does teaching experience increase teacher effectiveness? A review of US research. Journal of Professional Capital and Community, 4(4), 286-308. doi:10.1108/JPCC-12-2018-0032

Refnita, L. (2014). Students' grammatical problems in writing simple paragraphs: Lack of grammatical competency or language carelessness (a paper presented in SELT; June 2021, 2014). Padang, Indonesia. Retrieved from file:///C:/Users/pc/Downloads/671613368-1-

SM.pdf

Susanto, A., Salleh, B., \& Halim, F. (2018). The Perception of Lectures and Working Students Toward English Proficiency. AFBE International Conference. Retrieved from https://eudl.eu/doi/10.4108/eai.6- 12-2018.2286294., 22 February 2019.

Ulum, Ö. G. (2015). Listening: The Ignored Skill in EFL Context. International Journal of Humanities Social Sciences and Education (IJHSSE), 2(5), 72-76.

Yahaya, A., Yahaya, N., Lean, O. C., Bon, O. T., \& Ismail, S. (2011). Factors contributing to proficiency in English as a second language among Chinese students in Johor Bahru. Elixir Psychology, 41, 5837-5848.

Yolageldili, G., \& Arikan, A. (2011). Effectiveness of Using Games in Teaching Grammar to Young Learners. Elementary Education Online, 10(1), 219-229

Zain, N. M., Aspah, V., Abdullah, N., \& Ebrahimi, M. (2017). Challenges and evolution of higher education in Malaysia. UMRAN-International Journal of Islamic and Civilizational Studies, 4(1-1). 